\title{
EFEKTIVITAS FITOREMEDIASI DAN PROBIOTIK UNTUK MENINGKATKAN PERFORMA PERTUMBUHAN IKAN SIDAT, Anguilla bicolor PADA STADIA ELVER
}

\author{
Adang Saputra\#, Eri Setiadi, Yohana Retnaning Widyastuti, Nurhidayat, dan Tri Heru Prihadi \\ Balai Riset Perikanan Budidaya Air Tawar dan Penyuluhan Perikanan \\ Jl. Sempur No. 1, Bogor 16129
}

(Naskah diterima: 15 Juli 2021; Revisi final: 23 November 2021; Disetujui publikasi: 23 November 2021)

\begin{abstract}
ABSTRAK
Budidaya ikan sidat (Angguilla bicolor) pada stadia elver sudah menggunakan sistem intensif, penggunaan pakan formula dengan protein sekitar $50 \%$ sehingga berpotensi mempercepat proses toksisitas media pemeliharaan. Tujuan penelitian ini adalah mengevaluasi efektivitas dari fitoremediasi dan probiotik dalam meningkatkan performa pertumbuhan ikan sidat pada stadia elver. Seluruh rangkaian kegiatan percobaan dilaksanakan di Kelompok Delta Sidat, Dusun Krajan Desa Sidoluhur Kecamatan Ambal Kabupaten Kebumen Provinsi Jawa Tengah. Rancangan percobaan adalah rancangan acak lengkap (RAL) dengan tiga perlakuan dan tiga ulangan bak. Perlakuan yang diberikan adalah aplikasi: A) probiotik, B) fitoremediasi, dan C) kombinasi fitoremediasi dan probiotik. Padat tebar ikan uji pada masing-masing wadah pemeliharaan sebanyak 125 ekor dengan bobot awal rata-rata 10,66 \pm 1,01 g/ekor. Pakan yang diberikan adalah pakan formula dengan frekuensi pemberian tiga kali sehari sebanyak $5 \%$ dari jumlah biomassa. Hasil penelitian menunjukkan bahwa aplikasi kombinasi probiotik dan fitoremediasi (perlakuan-C) mampu mendegradasi nitrogen dan fosfor, sehingga mampu meningkatkan kinerja pertumbuhan elver. Hasil perhitungan terhadap kinerja pertumbuhan pada perlakuan-C menunjukkan sintasan mencapai 89,89\% biomassa akhir 35,57 kg; efisiensi penggunaan pakan $80,50 \%$ dan secara ekonomi sangat menguntungkan terlihat dari $\mathrm{B} / \mathrm{C}$ rasionya mencapai 3,01; serta rentabilitas sebesar $200,85 \%$ terhadap biaya yang digunakan. Sehingga aplikasi kombinasi fitoremediasi dan probiotik mampu meningkatkan produksi dan produktivitas elver dari sistem budidaya.
\end{abstract}

\section{KATA KUNCl: $\quad$ probiotik; fitoremediasi; sidat; elver; intensif}

ABSTRACT: Effectiveness of phytoremediation and probiotics to improve the growth performance of tropical eel, Anguilla bicolor, elver. By: Adang Saputra, Eri Setiadi, Yohana Retnaning Widyastuti, Nurhidayat, and Tri Heru Prihadi

An intensive system has been developed to culture tropical eel, Anguilla bicolor on elver stadia. However, the use of feed formula containing $50 \%$ protein has accelerated water quality degradation in the rearing media. This study aimed to evaluate the effectivity of phytoremediation and probiotics to improve the growth performance of eel elver. The research was conducted in Delta Sidat Group, Sidoluhur Village Ambal District, Kebumen, Central Java Province. The experimental design used was a completely randomized design with three treatments and three replicates. The treatments applied were: A) probiotic, B) phytoremediation, and C) combination of phytoremediation and probiotic. The stocking density used was 125 elver/container with an initial weight of $10.66 \pm 1.01 \mathrm{~g} /$ fish. The feed formula was given daily at $5 \%$ of total elver biomass. The result showed that the $C$ treatment was able to reduced nitrogen and phosphorus levels and to improve the growth performance of eel elver with a survival rate of $89.89 \%$ and the final average weight of $35.57 \mathrm{~kg}$, with feed efficiency of $80.50 \%$ The economic profitability calculated from the $\mathrm{B} / \mathrm{C}$ ratio reached 3.01 and rentability of $200.85 \%$ compared to the cost used. The study concludes that the combination of phytoremediation and probiotic can improve the production and economic profitability of eel culture on elver stadia.

KEYWORDS: probiotic; phytoremediation; eel; elver; intensive

* Korespondensi: Balai Riset Perikanan Budidaya Air Tawar dan Penyuluhan Perikanan. Jl. Sempur No. 1, Bogor 16129, Indonesia E-mail: adang_pusrisdkp@yahoo.com 


\section{PENDAHULUAN}

Ikan sidat, Anguilla bicolor termasuk pada kelompok ikan karnivora yang bersifat predator (Mutrini, 2015). Pada stadia elver, sumber makanan utama ikan sidat di alam adalah udang, kepiting, ikan, dan moluska yang sesuai dengan ukuran bukaan mulutnya (Baskoro et al., 2016). Sehingga kebutuhan nutrisi ikan sidat pada wadah budidaya memerlukan protein yang cukup tinggi untuk memenuhi nutrien tubuhnya. Pakan dengan kandungan protein tinggi pada sistem budidaya menghasilkan produk limbah dalam bentuk senyawa terlarut maupun padat terutama nitrogen dan fosfat (Dauda et al., 2019). Konsentrasi $\mathrm{N}$ dan $\mathrm{P}$ yang tinggi melebihi tingkat kemampuan ekosistem menyebabkan penurunan kualitas air (Devi et al., 2017; Endut et al., 2014).

Menurut Gunadi et al. (2013), tingginya konsentrasi $\mathrm{N}$ dan $\mathrm{P}$ berdampak pada penurunan kualitas lingkungan perairan, eutrofikasi, dan mengandung senyawa-senyawa toksik. Sementara itu, hasil penelitian Frid \& Dobson (2001) menunjukkan ikan budidaya akan melepaskan N dan P ke air sekitar 20\% yang berasal dari pakan, $10 \%$ feses, dan $15 \%$ berasal dari proses eksresi. Menurut Effendi (2003), partikel $\mathrm{N}$ yang terlarut dalam air terdiri atas amonia $\left(\mathrm{N}-\mathrm{NH}_{3}\right)$, amonium $\left(\mathrm{N}-\mathrm{NH}_{4}\right)$, nitrit $\left(\mathrm{N}-\mathrm{NO}_{2}\right)$, dan nitrat $\left(\mathrm{N}-\mathrm{NO}_{3}\right)$.

Semakin tinggi konsentrasi $\mathrm{N}$ dalam air berdampak langsung terhadap pertumbuhan dan imunitas ikan (Paust et al., 2011; Li et al., 2016). Menurut pendapat Cheng et al. (2015), amonia merupakan buangan metabolik, pada konsentrasi tertentu sangat beracun bagi organisme air. Hasil penelitian Dolezelova et al. (2011) menunjukkan pada kondisi amonia dan nitrit dalam air meningkat, akan bersifat toksik terhadap ikan maupun organisme akuatik lainnya. Hal ini berdampak terhadap rendahnya produksi dan produktivitas karena tingginya mortalitas ikan yang dibudidayakan (Setiadi \& Setijaningsih, 2011). Untuk itu, perlu dilakukan akselerasi teknologi budidaya yang sederhana, murah, dan ramah lingkungan untuk menurunkan tingkat pencemaran akibat dari limbah $\mathrm{N}$ dan $\mathrm{P}$ termasuk pada budidaya ikan sidat. Menurut Affandi et al. (2013), untuk mengatasi permasalahan tingginya polutan pada wadah budidaya ikan sidat, teknologi yang dapat digunakan di antaranya sistem resirkulasi dan probiotik.

Salah satu teknologi resirkulasi sederhana dan murah, serta dapat diaplikasikan oleh masyarakat adalah fitoremediasi. Menurut Nizam et al. (2020); Mardalen et al. (2018); Pulungan et al. (2020), sistem fitoremediasi yang digunakan harus mempunyai kemampuan dalam menstimulasi aktivitas biodegradasi oleh mikrobia yang berasosiasi dengan akar tanaman dan menyerap partikel dari dalam tanah. Hasil penelitian Saputra et al. (2017); Vesely et al. (2011), salah satu jenis tanaman air yang mempunyai kemampuan sebagai biofilter untuk menyerap polutan dalam air adalah eceng gondok (Eichornoa crassipes). Selain sebagai fitoremediasi, eceng gondok juga mempunyai kemampuan sebagai shelter pada pemeliharaan ikan gabus (Saputra \& Samsudin, 2017; Saputra \& Samsudin, 2018).

Selain aplikasi eceng gondok sebagai fitoremediasi, probiotik juga mempunyai kemampuan dalam mereduksi limbah pada sistem budidaya secara intensif (Gambar 1). Probiotik merupakan suplementasi sel mikroba utuh atau komponen sel mikroba pada lingkungan hidupnya yang menguntungkan inang. Proses bakterial probiotik dalam media budidaya merupakan salah satu solusi yang dapat dimanfaatkan untuk mengurangi beban pencemaran dan memperbaiki kualitas air (Gunadi et al., 2013; Lazado \& Caipang, 2014; Dimitroglou et al., 2011; Hindu et al., 2019). Tujuan dari penelitian ini adalah mengevaluasi efektivitas dari fitoremediasi dan probiotik dalam meningkatkan performa pertumbuhan ikan sidat pada stadia elver.

\section{BAHAN DAN METODE}

\section{Lokasi dan Waktu Penelitian}

Seluruh rangkaian kegiatan penelitian dilaksanakan di Kelompok Delta Sidat, Dusun Krajan Desa Sidoluhur Kecamatan Ambal Kabupaten Kebumen Provinsi Jawa Tengah. Waktu pelaksanaan penelitian pada bulan Februari sampai Juni 2020. Penentuan Kelompok Delta Sidat berdasarkan rekomendasi dari Dinas Kelautan dan Perikanan Kabupaten Banyumas dan sudah terdaftar sebagai kelompok pembudidaya ikan sidat dengan kelas kelompok madya. Kelompok tersebut secara teknis dan administrasi sudah memenuhi syarat sebagai mitra dalam penelitian pemeliharaan ikan sidat.

\section{Rancangan Percobaan}

Rancangan percobaan yang digunakan adalah rancangan acak lengkap (RAL), masing-masing perlakuan diulang tiga kali. Padat tebar ikan uji pada masing-masing wadah pemeliharaan sebanyak 125 ekor. Perlakuan yang diberikan adalah aplikasi: A) probiotik, B) fitoremediasi, dan C) kombinasi fitoremediasi dan probiotik. Pemeliharan elver dilakukan selama 90 hari masa pemeliharaan.

\section{Bahan dan Konstruksi Wadah Pemeliharaan}

Bahan utama yang digunakan dalam penelitian ini adalah benih ikan sidat dengan bobot rata-rata 10,66 $\pm 1,01 \mathrm{~g} /$ ekor (ukuran pensil) yang diperoleh dari nelayan pengumpul di daerah sekitar Kabupaten 


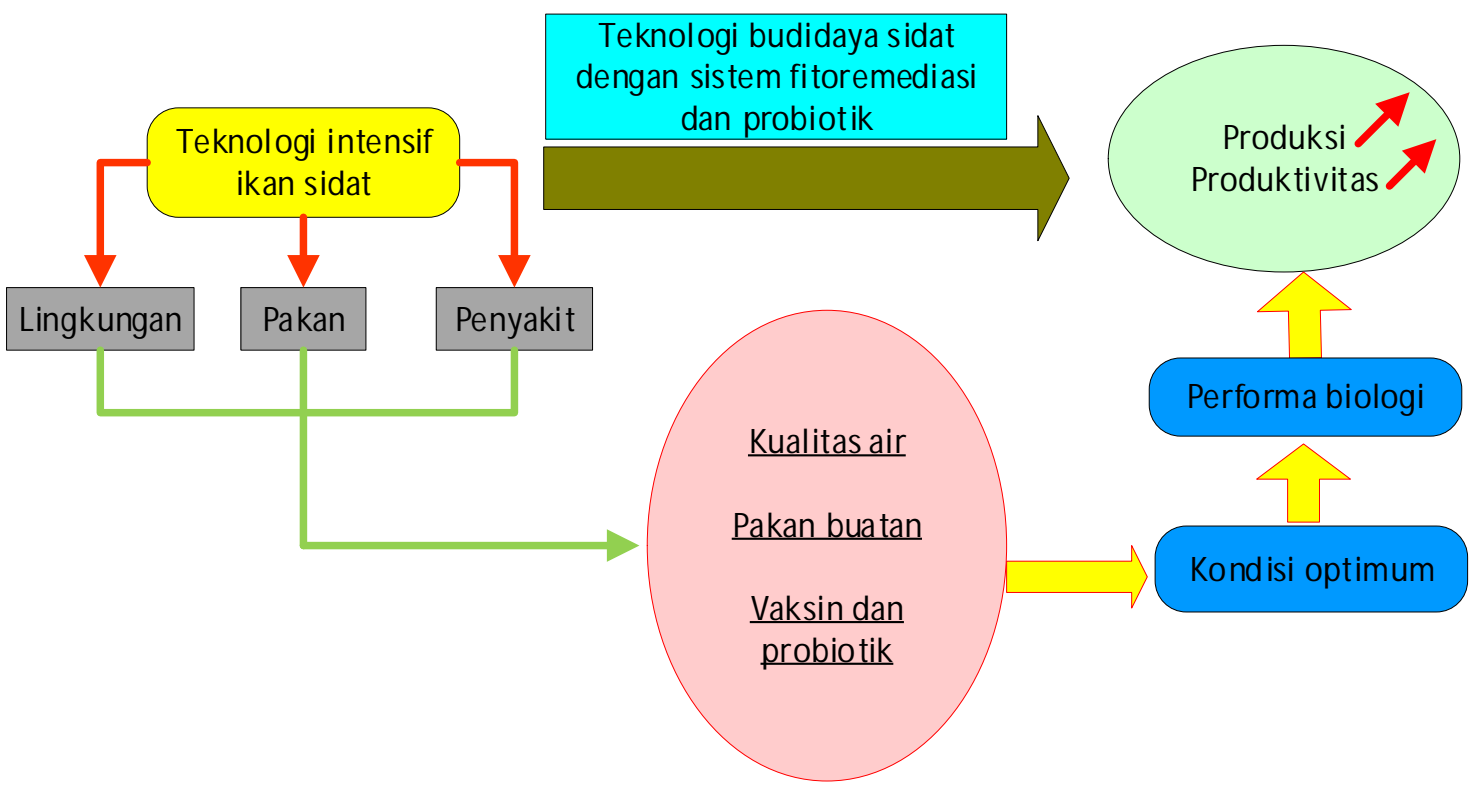

Gambar 1. Sistem budidaya ikan sidat secara intensif dengan aplikasi fitoremediasi dan probiotik.

Figure 1. Intensive system of eel culture with phytoremediation and probiotic applications.

Kebumen. Tanaman air yang digunakan adalah eceng gondok yang diperoleh dari masyarakat yang berada di sekitar Desa Sidoluhur. Probiotik yang digunakan adalah probiotik dengan multi mikroba yaitu Nitrobacter sp. dan Pseudomonas sp. yang diproduksi oleh Balai Riset Perikanan Budidaya Air Tawar dan Penyuluhan Perikanan (BRPBATPP) Bogor. Pakan yang digunakan adalah pakan khusus untuk ikan sidat dengan kandungan protein $50,63 \%$ lemak $43,47 \%$ kadar abu $5,10 \%$ serat kasar $0,7 \%$ dan BETN $0,10 \%$ dengan frekuensi pemberian tiga kali sehari sebanyak $5 \%$ dari bobot biomassa.

Wadah pemeliharaan benih ikan sidat adalah bak fiber dengan volume air dua ton sebanyak sembilan unit. Masing-masing bak fiber dilengkapi aerasi yang bersumber dari aerator. Penggunaan eceng gondok pada masing-masing wadah pemeliharaan sebanyak 5 $\mathrm{kg}$ dan ditimbang setiap minggunya supaya jumlahnya tetap sama (Gambar 2). Pemberian probiotik dilakukan setiap sepuluh hari sekali dengan dosis $10 \mathrm{~mL} /$ ton air. Air pemeliharaan tidak dilakukan pergantian selama penelitian. Penambahan air dilakukan ketika terjadi penurunan volume air akibat penguapan atau proses pembersihan dasar kolam.

\section{Pengambilan Sampel}

Penimbangan bobot individu dilakukan setiap satu bulan sekali, dengan cara mengambil secara acak

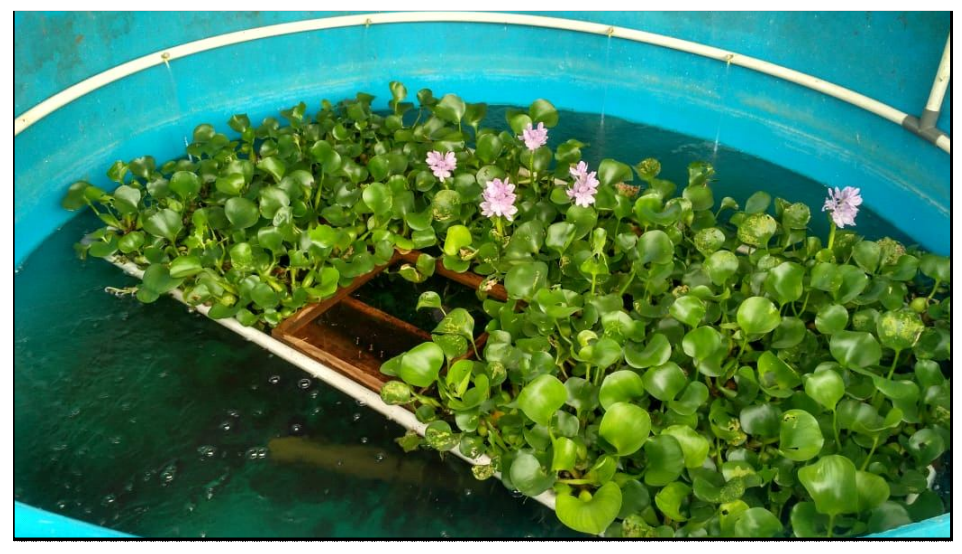

Gambar 2. Setting unit penelitian aplikasi fitoremediasi dan probiotik.

Figure 2. Setting up the research unit of phytoremediation and probiotics application. 
sebanyak 10 ekor dari total biomassa elver dari setiap wadah pemeliharaan. Data harian yang dicatat adalah kematian elver dan jumlah pemberian pakan. Pada akhir pemeliharaan dilakukan penghitungan jumlah ikan yang hidup dan total biomassanya. Parameter pertumbuhan yang dihitung adalah bobot akhir, sintasan, laju pertumbuhan spesifik (Zonneveld et al., 1991), dan kualitas air. Parameter kualitas air pada setiap wadah pemeliharaan diukur secara in situ (suhu, $\mathrm{pH}$, oksigen terlarut) dan ex situ meliputi amonia (SNI 06-6989.30-2005), nitrat (SNI 6989.79-2011), dan nitrit (SNI 06-6989.9-2005). Hasil pengukuran dan analisis terhadap parameter kualitas air disajikan dalam bentuk tabel dan dianalisis secara deskriptif. Data pertumbuhan ikan dianalisis dengan ANOVA pada selang kepercayaan 95\% Apabila terdapat perbedaan yang nyata, dilanjutkan dengan uji Duncant menggunakan program SPSS Versi 18. Pada akhir penelitian juga dilakukan analisis ekonomi.

\section{HASIL DAN BAHASAN}

\section{Kualitas Air}

Parameter kualitas air merupakan indikator kunci dalam keberhasilan budidaya ikan (Arifin et al., 2018; Purnamawati et al., 2017; Saputra \& Samsudin, 2017; Prihadi \& Pantjara, 2019). Hasil pengukuran parameter kualitas air pada pemeliharaan elver dengan aplikasi probiotik, fitoremediasi, dan kombinasi keduanya disajikan pada Tabel 1 . Hasil pengukuran terhadap suhu air menunjukkan pada seluruh perlakuan relatif sama yaitu berkisar antara $26,8^{\circ} \mathrm{C}-28,00^{\circ} \mathrm{C}$.
Kondisi ini masih dalam kisaran optimal untuk pertumbuhan ikan dan sesuai dengan hasil penelitian Courtenay \& Williams $(2004)$ berkisar $26^{\circ} \mathrm{C}-32^{\circ} \mathrm{C}$. Pada kondisi suhu optimum, proses metabolisme berjalan dengan baik, sehingga penyerapan nutrisi dari pakan sebagian besar digunakan untuk pertumbuhan.

Parameter kualitas air penting lainnya adalah $\mathrm{pH}$. Menurut Reynalte-Tataje et al. (2015), pH berperan penting terhadap sintasan dan pertumbuhan ikan. Nilai pH pada wadah pemeliharaan elver konsentrasinya masih stabil pada semua perlakuan. Namun pada aplikasi kombinasi antara fitoremediasi dan probiotik konsentrasinya mendekati nilai pH saturasi air, hal ini menandakan stabilitas $\mathrm{pH}$ dalam media pemeliharaan yang paling stabil. Kondisi ini menunjukkan bahwa sisa buangan metabolit dan pakan mampu didegradasi oleh tanaman air dan mikroba. Hal ini sejalan dengan hasil penelitian Boyd (1998) nilai pH cenderung lebih rendah dikarenakan terjadinya pemanfaatan sisa hasil fotosintesis, metabolisme, dan pakan yang tidak termanfaatkan oleh ikan.

Hasil pengukuran terhadap oksigen terlarut menunjukkan terjadinya perbedaan konsentrasi pada aplikasi probiotik dan fitoremediasi dengan kombinasi keduanya. Kandungan oksigen terlarut pada aplikasi probiotik (2,47-2,79 $\mathrm{mg} / \mathrm{L})$ dan fitoremediasi $(3,15-$ $3,28 \mathrm{mg} / \mathrm{L}$ ) masih berada di bawah batas ambang yang baik untuk budidaya ikan. Sedangkan pada aplikasi kombinasi antara fitoremediasi dan probiotik, kandungan oksigen terlarutnya berkisar antara 5,80$5,90 \mathrm{mg} / \mathrm{L}$. Menurut Wedemeyer (1996), oksigen

Tabel 1. Kisaran parameter kualitas air pemeliharaan elver pada aplikasi probiotik, fitoremediasi, dan kombinasi fitoremediasi dan probiotik

Table 1. The range of water quality parameters in the rearing media of elver cultured with probiotic, phytoremediation, and combination of phytoremediation and probiotic

\begin{tabular}{|c|c|c|c|c|}
\hline \multirow[b]{2}{*}{$\begin{array}{l}\text { Parameter } \\
\text { Parameters }\end{array}$} & \multicolumn{3}{|c|}{$\begin{array}{l}\text { Kisaran kualitas air (Perlakuan) } \\
\text { Range of waters quality (Treatments) }\end{array}$} & \multirow{2}{*}{$\begin{array}{l}\text { Kisaran } \\
\text { optimum } \\
\text { Optimum } \\
\text { range }\end{array}$} \\
\hline & $\begin{array}{l}\text { Probiotik } \\
\text { Probiotic }\end{array}$ & $\begin{array}{l}\text { Fitoremediasi } \\
\text { Phytoremediation }\end{array}$ & $\begin{array}{c}\text { Kombinasi fitoremediasi } \\
\text { dan probiotik } \\
\text { Combination of phytoremediation } \\
\text { and probiotic }\end{array}$ & \\
\hline Suhu $($ Temperature $)\left({ }^{\circ} \mathrm{C}\right)$ & $26.8-26.90$ & $27.7-27.80$ & $27.60-28.00$ & $26-32^{\mathrm{a}}$ \\
\hline $\mathrm{pH}$ & $6.62-6.70$ & $6.73-6.85$ & $7.00-7.02$ & $4.25-9.40^{c}$ \\
\hline $\begin{array}{l}\text { Oksigen terlarut } \\
\text { Dissolved oxygen (mg/L) }\end{array}$ & $2.47-2.79$ & $3.15-3.28$ & $5.80-5.90$ & $>5^{\mathrm{a}}$ \\
\hline $\begin{array}{l}\text { Total amonia nitrogen } \\
\text { Total ammonia nitrogen (mg/L) }\end{array}$ & $0.08-0.32$ & $0.08-0.33$ & $0.08-0.32$ & $? 1.57^{\mathrm{c}}$ \\
\hline Nitrit (Nitrite) (mg/L) & $0.02-0.04$ & $0.01-0.04$ & $0.01-0.03$ & $<0.1^{\mathrm{b}}$ \\
\hline Nitrat (Nitrate) (mg/L) & $2.45-6.55$ & $2.55-6.67$ & $2.47-5.99$ & $<20^{b}$ \\
\hline
\end{tabular}

Keterangan (Remarks): a) Courtenay \& Williams (2004); b) Boyd (1998); c) Wedemeyer (1996) 
terlarut dalam air yang baik berada pada kisaran $>5$ $\mathrm{mg} / \mathrm{L}$. Rendahnya kandungan oksigen terlarut berdampak terhadap tingkat kelangsungan hidup elver karena terjadi kompetisi oksigen yang berlebihan. Pada kondisi kekurangan oksigen, ikan tidak mampu untuk memenuhi oksigen tubuhnya sehingga mengakibatkan kematian.

Amonia, nitrat, dan nitrit merupakan parameter kualitas air yang bersifat toksik apabila melebihi ambang batas yang ditoleransi (Cheng et al., 2015; Dolezelova et al., 2011). Hasil pengukuran terhadap total amonia nitrogen pada aplikasi probiotik berkisar 0,08-0,32 mg/L; fitoremediasi berkisar 0,08-0,33 mg/ L; dan kombinasi keduanya berkisar antara 0,08-0,32 $\mathrm{mg} / \mathrm{L}$. Hasil pengukuran terhadap nitrit pada aplikasi probiotik berkisar 0,02-0,04 mg/L; fitoremediasi berkisar 0,01-0,04 mg/L; dan kombinasi keduanya berkisar antara 0,01-0,02 mg/L. Hasil pengukuran terhadap nitrat menunjukkan pada aplikasi probiotik berkisar 2,45-6,55 mg/L; fitoremediasi 2,55-6,67 mg/ L; dan kombinasi keduanya berkisar antara 2,47-5,99 $\mathrm{mg} / \mathrm{L}$. Hasil pengukuran terhadap parameter amonia, nitrit, dan nitrat menunjukkan masih di bawah ambang batas toksik untuk pemeliharaan ikan (Boyd, 1998; Wedemeyer, 1996). Karena semakin tinggi konsentrasi nitrogen dalam air berdampak langsung terhadap pertumbuhan dan imunitas ikan (Paust et al., 2011; Li et al., 2016). Kondisi kualitas air pada pemeliharaan elver dengan aplikasi probiotik dan fitoremediasi mampu mendegradasi limbah nitrogen dan fosfor sehingga air tidak menjadi toksik (Samsundari \& Wirawan, 2013). Namun pada aplikasi kombinasi antara fitoremediasi dan probiotik relatif paling rendah dibandingkan dengan yang lainnya. Pada kondisi kualitas air tidak toksik, kinerja pertumbuhan dan perkembangan elver menjadi optimal.

\section{Kinerja Pertumbuhan}

Hasil penelitian menunjukkan indikator kinerja pertumbuhan elver pada aplikasi probiotik, fitoremediasi, dan kombinasi keduanya menunjukkan pertambahan bobot rata-rata sampai hari ke-30 masa pemeliharaan tidak berbeda nyata $(P>0,05)$, mulai hari ke-60 sampai akhir pemeliharaan menunjukkan peningkatan yang sangat nyata $(P<0,05)$ antar perlakuan (Gambar 3). Pertambahan bobot rata-rata akhir pada aplikasi probiotik $(70,27 \pm 4,52$ g/ekor $)$ dengan aplikasi fitoremediasi $(64,40 \pm 3,55$ g/ekor) tidak berbeda secara nyata ( $P>0,05)$; namun kedua perlakuan tersebut berbeda secara nyata $(P>0,05)$ dengan aplikasi kombinasi keduanya $(105,56 \pm 4,38$ g/ekor). Hasil ini berkorelasi positif dengan laju pertumbuhan spesifik pada aplikasi probiotik mencapai $0,66 \pm 0,05 \%$ hari; aplikasi fitoremediasi
$0,59 \pm 0,04 \%$ hari; serta aplikasi kombinasi fitoremediasi dan probiotik mencapai $1,05 \pm 0,05 \%$ hari (Tabel 2).

Selain indikator kinerja pertumbuhan yang terlihat lebih baik pada aplikasi kombinasi fitoremediasi dan probiotik, juga sintasan, biomassa, dan jumlah konsumsi pakan. Sintasan pada aplikasi kombinasi antara fitoremediasi dan probiotik mencapai 89,87 $\pm 0,85 \%$ berbeda sangat nyata $(P<0,05)$ dengan aplikasi probiotik $(68,27 \pm 1,66 \%$ dan fitoremediasi $(65,33 \pm 1,81 \%$. Hasil ini berpengaruh terhadap jumlah biomassa akhir mencapai 35,57 $\pm 3,61 \mathrm{~kg}$ untuk kombinasi fitoremediasi dan probiotik, serta berbeda sangat nyata $(P<0,05)$ dengan aplikasi probiotik dan fitoremediasi (Tabel 2). Namun demikian, jumlah konsumsi pakan pada semua perlakuan tidak berbeda secara nyata $(P>0,05)$ baik pada aplikasi probiotik, fitoremediasi maupun pada kombinasi antara fitoremediasi dan probiotik (Tabel 2). Hasil ini sesuai dengan hasil penelitian Soeprijanto et al. (2018) yaitu aplikasi probiotik dan pakan fermentasi mampu meningkatkan sintasan, pertumbuhan, serta menurunkan rasio konversi pakan pada pendederan sidat.

Hasil ini menunjukkan bahwa proses nitrifikasi dan denitrifikasi pada aplikasi fitoremediasi dan probiotik berjalan dengan baik untuk mengurai total nitrogen dan fosfor. Karena limbah nitrogen dan fosfor dapat dikendalikan, sehingga ikan tidak stres, nafsu makan, dan imunitas tinggi, sehingga menurunkan mortalitas (Aquarista et al., 2012). Menurut Nowosad et al. (2013), bahwa total nitrogen dan fosfor dalam konsentrasi tertentu memiliki dampak negatif terhadap penurunan kualitas air.

Eceng gondok selain mempunyai kemampuan mendegradasi nitrogen dan fosfor, juga berfungsi sebagai naungan (shelter) untuk meningkatkan pertumbuhan dan sintasan ikan (Saputra \& Samsudin, 2017). Hal tersebut terlihat dari performa pertumbuhan dan efisiensi pakan pada aplikasi kombinasi fitoremediasi dan probiotik relatif lebih tinggi dibandingkan dengan aplikasi masing-masing.

\section{Analisis Ekonomi}

Hasil analisis ekonomi secara sederhana menunjukkan produksi elver pada aplikasi probiotik, fitoremediasi, serta kombinasi antara fitoremediasi dan probiotik menunjukkan perbedaan keuntungan yang diperoleh secara signifikan khususnya pada aplikasi kombinasi fitoremediasi dan probiotik. Hasil analisis ekonomi (Tabel 3), untuk memproduksi elver dalam tiga bak fiber kapasitas air dua ton dengan aplikasi probiotik membutuhkan biaya untuk 


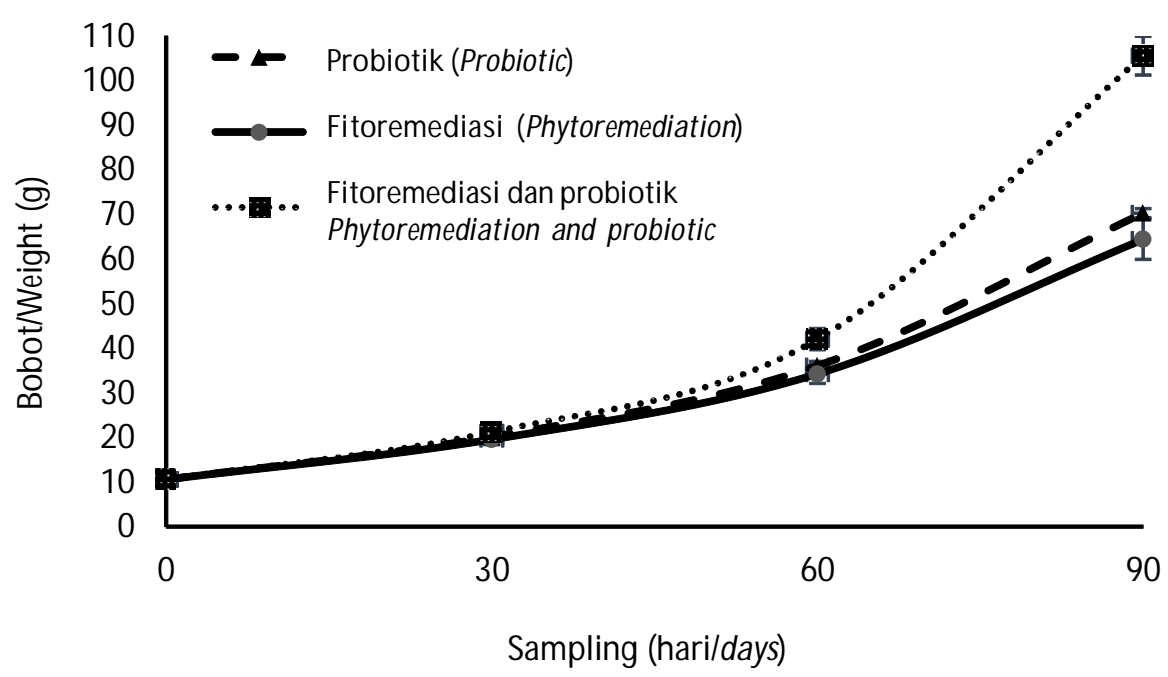

Gambar 3. Performa pertambahan bobot rata-rata elver dengan aplikasi probiotik, fitoremediasi, dan kombinasi fitoremediasi dengan probiotik selama 90 hari masa pemeliharaan.

Figure 3. Elver's average weight gain performance with probiotic, phytoremediation, and combination of phytoremediation; and probiotic applications during the 90-day intensive culture.

pembelian elver, pakan formula, aerator, pompa air, listrik, dan probiotik. Jumlah biaya yang diperlukan dalam satu siklus produksi sebesar Rp3.385.000,00. Hasil penjualan elver dalam satu siklus produksi mencapai Rp5.397.000,00. Sehingga keuntungan bersih produksi elver dengan aplikasi probiotik mencapai Rp2.012.00,00/siklus. Dalam kondisi ini, pembudidaya masih layak untuk meneruskan usaha produksi elver karena nilai $\mathrm{B} / \mathrm{C}$ rasionya mencapai 1,59\% dengan keuntungan sebesar 59,48\% terhadap biaya yang digunakan.

Tabel 2. Rata-rata bobot awal, rata-rata bobot akhir, laju pertumbuhan spesifik, sintasan, biomassa awal, biomassa akhir, dan jumlah konsumsi pakan

Table 2. Initial average body weight, average final body weight, specific growth rate, survival, initial biomass, final biomass, and total given feed

\begin{tabular}{|c|c|c|c|}
\hline \multirow[b]{2}{*}{$\begin{array}{l}\text { Parameter } \\
\text { Parameters }\end{array}$} & \multicolumn{3}{|c|}{ Perlakuan (Treatments ) } \\
\hline & $\begin{array}{l}\text { Probiotik } \\
\text { Probiotic }\end{array}$ & $\begin{array}{l}\text { Fitoremediasi } \\
\text { Phytoremediation }\end{array}$ & $\begin{array}{c}\text { Kombinasi fitoremediasi } \\
\text { dan probiotik } \\
\text { Combination of phytoremediation } \\
\text { and probiotic }\end{array}$ \\
\hline $\begin{array}{l}\text { Rata-rata bobot awal } \\
\text { Average initial body weight (g) }\end{array}$ & $10.66 \pm 0.77^{a}$ & $10.66 \pm 0.77^{a}$ & $10.66 \pm 0.77^{a}$ \\
\hline $\begin{array}{l}\text { Rata-rata bobot akhir } \\
\text { Average final body weight (g) }\end{array}$ & $70.27 \pm 4.52^{\mathrm{a}}$ & $64.40 \pm 3.55^{\mathrm{a}}$ & $105.56 \pm 4.38^{b}$ \\
\hline $\begin{array}{l}\text { Laju pertumbuhan sepesifik (\%/hari) } \\
\text { Specific growth rate (\%/day) }\end{array}$ & $0.66 \pm 0.05^{\mathrm{a}}$ & $0.59 \pm 0.04^{\mathrm{a}}$ & $1.05 \pm 0.05^{b}$ \\
\hline Sintasan (Survival) (\%) & $68.27 \pm 1.66^{a}$ & $65.33 \pm 1.81^{a}$ & $89.87 \pm 0.85^{b}$ \\
\hline Biomassa awal (Initial biomass) (kg) & $4 \pm 0.1^{a}$ & $4 \pm 0.2^{\mathrm{a}}$ & $4 \pm 0.1^{\mathrm{a}}$ \\
\hline Biomassa akhir (Final biomass) (kg) & $17.98 \pm 3.75^{\mathrm{a}}$ & $15.78 \pm 2.78^{\mathrm{a}}$ & $35.57 \pm 3.61^{b}$ \\
\hline $\begin{array}{l}\text { Jumlah pakan yang diberikan } \\
\text { Total given feed }(\mathrm{kg})\end{array}$ & $72.00 \pm 3.22^{\mathrm{a}}$ & $70.50 \pm 5.92^{\mathrm{a}}$ & $80.50 \pm 5.52^{a}$ \\
\hline
\end{tabular}

Keterangan: Angka yang diikuti huruf superskrip yang berbeda menunjukkan hasil yang sangat berbeda nyata $(P<0,05)$ Remaks: (Numbers followed by different superscript letters indicate significant difference $(P<0.05)$ ) 
Hasil analisis ekonomi elver dengan aplikasi fitoremediasi disajikan pada Tabel 4, namun hasilnya masih lebih baik dibandingkan produksi elver dengan aplikasi probiotik (Tabel 3). Untuk memproduksi elver dalam tiga bak fiber kapasitas air dua ton dengan aplikasi fitoremediasi membutuhkan biaya untuk pengadaan elver, pakan formula, aerator, pompa air, dan listrik. Total biaya operasional yang dikeluarkan untuk memproduksi elver mencapai Rp3.167.000,00 dan hasil penjualan mencapai Rp4.734.000,00. Pada kondisi ini memberikan keuntungan sebesar Rp1.567.000,00/siklus/tiga bak fiber. Pada kondisi ini, pembudidaya masih layak untuk meneruskan usaha produksi elver karena nilai R/C rasionya 1,49\%dengan

Tabel 3. Analisis ekonomi budidaya elver dengan aplikasi probiotik

Table 3. Economic analysis of elver culture using probiotic application

\begin{tabular}{|c|c|c|c|c|}
\hline $\begin{array}{l}\text { Keterangan } \\
\text { Description }\end{array}$ & Volume & $\begin{array}{c}\text { Satuan } \\
\text { Unit }\end{array}$ & $\begin{array}{l}\text { Harga satuan } \\
\text { Unit price (Rp) }\end{array}$ & $\begin{array}{l}\text { Jumlah } \\
\text { Amount (Rp) }\end{array}$ \\
\hline \multicolumn{5}{|c|}{ Biaya operasional (per siklus) (Operational cost (per cycle)) } \\
\hline Benih (Seed) & 4 & $\mathrm{Kg}$ & 262,500 & $1,050,000$ \\
\hline Pakan (Feed) & 72 & $\mathrm{Kg}$ & 18,000 & $1,296,000$ \\
\hline Aerator (Aerator) & 1 & Unit & 295,000 & 295,000 \\
\hline Pompa air (Water pump) & 1 & Unit & 175,000 & 175,000 \\
\hline Listrik 35 watt (Electric 35 watt) & 3,150 & Watt & 120 & 378,000 \\
\hline Probiotik (Probiotic) & 2 & Botol (Bottle) & 100,000 & 200,000 \\
\hline \multicolumn{4}{|c|}{ Total biaya (Total cost ) (Rp) } & $3,385,000$ \\
\hline $\begin{array}{l}\text { Penerimaan (Revenue) } \\
\text { Produksi sidat (Elver production) } \\
\text { Laba (Profit) }\end{array}$ & 18 & $\mathrm{Kg}$ & 300,000 & $5,400,000$ \\
\hline Laba per siklus (Profit per cycle) & & & & $2,012,000$ \\
\hline Laba per tahun (Profit per year ) & & & & $6,036,000$ \\
\hline $\mathrm{R} /$ C rasio $(\mathrm{R} / \mathrm{C}$ ratio ) & & & & 1.59 \\
\hline $\begin{array}{l}\text { Rentabilitas ekonomi } \\
\text { Economic profitability (\%) }\end{array}$ & & & & 59.44 \\
\hline
\end{tabular}

Tabel 4. Analisis ekonomi budidaya elver dengan aplikasi fitoremediasi

Table 4. Economic analysis of elver culture using phytoremediation application

\begin{tabular}{|c|c|c|c|c|}
\hline $\begin{array}{l}\text { Keterangan } \\
\text { Description }\end{array}$ & Volume & $\begin{array}{l}\text { Satuan } \\
\text { Unit }\end{array}$ & $\begin{array}{l}\text { Harga satuan } \\
\text { Unit price (Rp) }\end{array}$ & $\begin{array}{l}\text { Jumlah } \\
\text { Amount (Rp) }\end{array}$ \\
\hline \multicolumn{5}{|c|}{ Biaya operasional (per siklus) (Operational cost (per cycle)) } \\
\hline Benih (Seed) & 4 & $\mathrm{Kg}$ & 262,500 & $1,050,000$ \\
\hline Pakan (Feed) & 70.50 & $\mathrm{Kg}$ & 18,000 & $1,269,000$ \\
\hline Aerator (Aerator) & 1 & Unit & 295,000 & 295,000 \\
\hline Pompa air (W ater pump ) & 1 & Unit & 175,000 & 175,000 \\
\hline Listrik 35 watt (Electric 35 watt) & 3.15 & Watt & 120,000 & 378,000 \\
\hline \multicolumn{4}{|c|}{ Total biaya (Total cost) (Rp) } & $3,167,000$ \\
\hline \multicolumn{5}{|l|}{ Penerimaan (Revenue) } \\
\hline Produksi sidat (Elver production ) & \multicolumn{2}{|c|}{$15.78 \mathrm{Kg}$} & 300.000 & $4,734.00$ \\
\hline \multicolumn{5}{|l|}{ Laba (Profit) } \\
\hline Laba per siklus (Profit per cycle) & & & & $1,567,000$ \\
\hline Laba per tahun (Profit per year) & & & & $4,701,000$ \\
\hline $\mathrm{R} / \mathrm{C}$ rasio $(\mathrm{R} / \mathrm{C}$ ratio $)$ & & & & 1.49 \\
\hline $\begin{array}{l}\text { Rentabilitas ekonomi } \\
\text { Economic profitability (\%) }\end{array}$ & & & & 49.48 \\
\hline
\end{tabular}


keuntungan mencapai $49,48 \%$ terhadap biaya yang digunakan, namun lebih rendah apabila dibandingkan dengan aplikasi probiotik.

Hasil perhitungan ekonomi terhadap produksi elver pada aplikasi kombinasi fitoremediasi dan probiotik disajikan pada Tabel 5. Biaya operasional yang dibutuhkan untuk memproduksi elver dalam tiga bak fiber kapasitas air dua ton untuk mengadakan elver, pakan formula, aerator, pompa air, listrik, dan probiotik. Total biaya operasional yang dikeluarkan untuk memproduksi elver mencapai Rp3.547.000,00 dengan hasil penjualan mencapai Rp10.671.000,00. Keuntungan bersih yang diperoleh pada produksi elver dengan aplikasi kombinasi antara fitoremediasi dan probiotik mencapai Rp7.124.000,00/siklus/tiga bak fiber. Dalam kondisi ini, pembudidaya sangat layak untuk usaha produksi elver karena nilai $\mathrm{B} / \mathrm{C}$ rasionya 3,01\%dengan keuntungan mencapai 200,85\%terhadap biaya yang digunakan.

Hasil analisis ekonomi sederhana menunjukkan bahwa penggunaan fitoremediasi bersama-sama dengan probiotik mampu memperbaiki kualitas air melalui proses nitrifikasi dan denitrifikasi sisa buangan metabolik berupa nitrogen dan fosfor sehingga tidak menjadi racun. Selain mendegradasi sisa buangan metabolik, fitoremediasi juga berfungsi sebagai naungan, sehingga elver dapat tumbuh dan berkembang dengan optimal. Secara ekonomi, usaha budidaya ikan sidat pada stadia elver dengan aplikasi kombinasi fitoremediasi dan probiotik sangat menguntungkan.

\section{KESIMPULAN}

Budidaya ikan sidat pada stadia elver di Kabupaten Kebumen dengan aplikasi kombinasi fitoremediasi dan probiotik memberikan hasil yang lebih baik dibandingkan dengan aplikasi fitoremediasi atau probiotik secara terpisah. Performa pertumbuhan elver yang dipelihara dengan aplikasi kombinasi fitoremediasi dengan probiotik paling efektif dalam meningkatkan sintasan $(89,897 \%$, biomassa akhir $(35,57 \mathrm{~kg})$, efisiensi penggunaan pakan $(80,50 \%$, serta mampu memberikan keuntungan secara ekonomi dengan rentabilitas mencapai $200,85 \%$ dan $B / C$ rasio 3,01 .

\section{UCAPAN TERIMA KASIH}

Diucapkan terima kasih kepada Kepala Balai Riset Perikanan Budidaya Air Tawar dan Penyuluhan Perikanan yang berkenan memfasilitasi kegiatan ini. Ucapan terima kasih juga kami sampaikan kepada Dinas Perikanan dan Kelautan Kabupaten Kebumen, Bapak Sigit Dwi Purnomo selaku Kepala Bidang Usaha Perikanan yang telah banyak membantu kegiatan ini dan Bapak Saifun sebagai Ketua Kelompok Delta Sidat. Kegiatan Riset ini di biayai oleh DIPA BRPBATPP Tahun Anggaran 2020.

Tabel 5. Analisis ekonomi budidaya elver dengan aplikasi kombinasi fitoremediasi dan probiotik Table 5. Economic analysis of elver culture using combination phytoremediation and probiotic application

\begin{tabular}{|c|c|c|c|c|}
\hline $\begin{array}{l}\text { Keterangan } \\
\text { Description }\end{array}$ & Volume & $\begin{array}{c}\text { Satuan } \\
\text { Unit }\end{array}$ & $\begin{array}{l}\text { Harga satuan } \\
\text { Unit price (Rp) }\end{array}$ & $\begin{array}{l}\text { Jumlah } \\
\text { Amount (Rp) }\end{array}$ \\
\hline \multicolumn{5}{|c|}{ Biaya operasional (per siklus) (Operational cost (per cycle)) } \\
\hline Benih (Seed) & 4 & $\mathrm{Kg}$ & 262,500 & $1,050,000$ \\
\hline Pakan (Feed) & 80.50 & $\mathrm{Kg}$ & 18,000 & $1,449,000$ \\
\hline Aerator (Aerator) & 1 & Unit & 295,000 & 295,000 \\
\hline Pompa air (W ater pump) & 1 & Unit & 175,000 & 175,000 \\
\hline Listrik 35 watt (Electric 35 watt) & 3.150 & Watt & 120 & 378.000 \\
\hline Probiotik (Probiotic) & 2 & Botol & 100,000 & 200,000 \\
\hline \multicolumn{3}{|c|}{ Total biaya (Total cost) (Rp) } & & 3.547 .000 \\
\hline $\begin{array}{l}\text { Penerimaan (Revenue) } \\
\text { Produksi sidat (Elver production) }\end{array}$ & 35.57 & $\mathrm{Kg}$ & 300 & 10.671 .000 \\
\hline \multicolumn{5}{|l|}{ Laba (Profit) } \\
\hline Laba per siklus (Profit per cycle) & & & & 7.124 .000 \\
\hline Laba per tahun (Profit per year) & & & & 21.372 .000 \\
\hline $\mathrm{R} / \mathrm{C}$ rasio $(\mathrm{R} / \mathrm{C}$ ratio $)$ & & & & 3.01 \\
\hline $\begin{array}{l}\text { Rentabilitas ekonomi } \\
\text { Economic profitability (\%) }\end{array}$ & & & & 200.85 \\
\hline
\end{tabular}




\section{DAFTAR ACUAN}

Affandi, R., Budiardi, B., Wahju, R.I., \& Taurusman, A.A. (2013). Pemeliharaan ikan sidat dengan sistem air bersirkulasi. Jurnal IImu Pertanian Indonesia, 18(1), 55-60.

Aquarista, F., Iskandar, \& Subhan, U. (2012). Pembesaran probiotik dengan carier zeolit pada pembesaran ikan lele dumbo (Clarias gariepinus). Jurnal Perikanan dan Kelautan, 3(4), 133-140.

Arifin, O.Z., Prakoso, V.A., \& Pantjara, B. (2018). Ketahanan ikan tambakan (Helostoma temminkii) terhadap beberapa parameter kualitas air dalam lingkungan budidaya. Jurnal Riset Akuakultur, 12(3), 241-251.

Baskoro, M.S., Purbayanto, A., Haluan, J., Nuitja, I.N.S., Sulistiyono, Affandi, R., Sumantadinata, K., ......, $\&$ Jaya, I. (2016). Teknologi pengembangan perikanan dan kelautan untuk memperkuat ketahanan pangan serta memacu perekonomian nasional secara berkelanjutan. IPB Press, 150 pp.

Boyd, C. (1998). Water quality for pond aquaculture. Alabama: International Centre for Aquaculture and Aquatic Environments. Alabama Agricultural Experiment Station, Auburn University. 163 pp.

Cheng, C.H., Yang, F.F., Ling, R.Z., Liao, S.A., Miao, Y.T., Ye, C.X., \& Wang, A.L. (2015). Effects of ammonia exposure on apoptosis, oxidative stress and immune response in pufferfish (Takifugu obscurus). Aquatic Toxicology, 164, 61-71.

Courtenay, W.R. \& Williams, J.D. (2004). Snakeheads (Pisces, Channidae): A biological synopsis and risk assessment. US Geological Survey, 143 pp.

Dauda, A.B., Ajadi, A.L., Tola-Fabunmi, A.S., \& Akniwole, A.O. (2019). Waste production in aquaculture: Sources, components and managments in different culture system. Aquacultur and Fisheries, 4, 81-88.

Dimitroglou, A., Merrifield, D., Carnevali, O., Picchietti, S., Avella, M., Daniels, C., Guroy, D,. \& Davies, S.J. (2011). Microbial manipulations to improve fish health and production-a M editerranean perspective. Fish \& Shell fish Immunology, 30(1), 116.

Devi, P.A., Padmavathy, P., Aanand, S., \& Aruljothi, K. (2017). Review on water quality parameters in freshwater cage fish culture. International Journal of Applied Research, 3(5), 114-120.

Dolezelova, P., Macova, S., Pistekova, V., Svobodova, Z., Bedanova, I., \& Voslarova, E. (2011). Nitrite toxicity assessment in Danio rerio and Poecilia reticulata. Acta Veterinaria Brno, 80(3), 309-312.
Effendi, H. (2003). Telaah kualitas air bagi pengelolaan sumberdaya dan lingkungan perairan. Yogyakarta: Kanisisus, $237 \mathrm{pp}$.

Endut, A., Jusoh, A., \& Ali, N. (2014). Nitrogen budget and effluent nitrogen components in aquaponics recirculation system. Desalination and Water Treatment, 52(4-6), 744-752.

Frid, C. \& Dobson, M. (2001). Ecology of aquatic management. Prentice Hall. New York, 352 pp.

Gunadi, B., Haris, E., Supriyono, E., Sukenda, \& Budiardi, T. (2013). Ketercernaan protein dan ekresi ammonia pada pemeliharaan ikan lele Clarias gariepinus. Jurnal Akuakultur Indonesia, 12(1), 62-69.

Hindu, S.V., Chandrasekaran, N., Mukherjee, A., \& Thomas, J. (2019). A review on the impact of seaweed polysaccharide on the growth of probiotic bacteria and its application in aquaculture. Aquaculture International, 27, 227-238.

Lazado, C.C. \& Caipang, C.M.A. (2014). Mucosal immunity and probiotics in fish. Fish $\&$ Shellfish Immunology, 39(1), 78-89.

Li, M., Gong, S., Li, Q., Yuan, L., Meng, F., \& Wang, R. (2016). Ammonia toxicity induces glutamine accumulation, oxidative stress and immunosuppression in juvenile yellow catfish Pelteobagrus fulvidraco. Comparative Biochemistry and Physiology Part C: Toxicology \& Pharmacology, 183-184, 1-6.

Mardalen, Faizal, M. \& Napoleon, A. (2018). The absorption of iron ( $\mathrm{Fe}$ ) and manganese $(\mathrm{Mn})$ from coal mining wastewater with phytoremediation technique using floating fern (Salvinia natans), water lettuce (Pistia stratiotes) and water hyacinth (Eichornia crassipes). Biological Research Journal, 4(1), 32-38.

Mutrini, S. (2015). Makanan alami dan perkembangan anatomi saluran pencernaan ikan sidat (Anguilla bicolor McClelland 1944) dari Muara Sungai Cimandiri, Pelabuhan Ratu, Jawa Barat. Tesis. Sekolah Pascasarjana Institut Pertanian Bogor, $52 \mathrm{hlm}$.

Nizam, N.U.M., Hanafiah, M.M., Noor, I.M., \& Karim, H.I.A. (2020). Efficiency of five selected plants in phytroremediation of aquaculture wastewater. Applied Sciences, 10, 1-11.

Nowosad, J., Zarski, D., Bilas, M., Dryl, K., Krejszeff, S., \& Kucharczyk, D. (2013). Dynamics of ammonia excretion in juvenile common tench, Tinca tinca (L.), during intensive rearing under controlled conditions. Aquaculture International, 21, 629-637. 
Paust, L.O., Foss, A., \& Imsland, A.K. (2011). Effects of chronic and periodic exposure to ammonia on growth, food conversion efficiency and blood physiology in juvenile atlantic halibut (Hippoglossus hippoglossus L.). Aquaculture, 315(3-4), 400-406.

Prihadi, T.H. \& Pantjara, B. (2019). Penerapan remediasi pada sistem budidaya udang di tambak tanah sulfat masam (Studi kasus di Kabupaten Berau, Kalimantan Timur). M edia Akuakultur, 14(1), 5562.

Pulungan, L., Zaenal, Z., Ashari, Y., \& Megantara, F. (2020). Gold water treatment, waste monitoring, and management with the fitoremediation method. IOP Conference Series: Materials Science and Engineering. OP Conf. Series: Materials Science and Engineering, 830(042048): 1-9.

Purnamawati, Djokosetiyanto, D., Nirmala, K., Surawidjaja, E.H., \& Affandi, R. (2017). Respons kelangsungan hidup dan pertumbuhan juvenil ikan gabus Channa striata Bloch pada air rawa pasang surut dengan dan tanpa aerasi. Jurnal Akuakultur Indonesia, 16(1), 60-67.

Reynalte-Tataje, D.A., Baldisserotto, B., \& ZaniboniFilho, E. (2015). The effect of water pH on the incubation and larviculture of curimbata Prochilodus lineatus (Valenciennes, 1837) (Characiformes: Prochilodontidae). Neotropical Ichthyology, 13(1), 179-186.

Samsundari, S. \& Wirawan, G.A. (2013). Analisis penerapan biofilter dalam sistem resirkulasi terhadap mutu kualitas air budidaya ikan sidat (Anguilla bicolor). Jurnal Gamma, 8(2), 86-97.

Saputra, A. \& Samsudin, R. (2017). Penentuan jenis gulma air sebagai naungan (shelter) pada pendederan ikan gabus Channa striata di kolam. Jurnal Perikanan dan Kelautan, 7(2), 100-111.

Saputra, A. \& Samsudin, R. (2018). Penggunaan eceng gondok Eichornoa crassipes sebagai naungan pada pendederan ikan gabus Channa striata di kolam. Jurnal Perikanan dan Kelautan, 8(1), 19-30.

Saputra, A., Setijaningsih, L., Yosmaniar, \& Prihadi, T.H. (2017). Distribusi nitrogen dan fosfor pada budidaya ikan gabus Channa striata dengan aplikasi eceng gondok Eichhornia crassipes dan probiotik. Jurnal Riset Akuakultur, 12(4), 379-388.

Setiadi, E. \& Setijaningsih, L. (2011). Improving water quality and productivity of tilapia (Oreochromis niloticus) using constructed wetland. Indonesian Aquaculture Journal, 6(2), 107-122.

Soeprijanto, A., Guntur, \& Fakhri, M. (2018). Aplikasi probiotik dan pakan fermentasi pada pendederan sidat (Anguilla bicolor). Jurnal Perikanan Universitas Gadjah Mada, 20(1), 19-22.

Standar Nasional Indonesia (SNI) 06-6989.9-2005. Air dan air limbah, Bagian 9: Cara uji nitrit (NO2_N) secara spektrofotometri. ICS 13.060.50.

Standar Nasional Indonesia (SNI) 06-6989.30-2005. Air dan air limbah, Bagian 30: Cara uji kadar amonia dengan spektrofotometer secara fenat. ICS 13.060.01.

Standar Nasional Indonesia (SNI) 6989.79-2011. Air dan air limbah, Bagian 79: Cara uji nitrat $\left(\mathrm{NO}_{3}-\mathrm{N}\right)$ dengan spektrofotometer UV-visibel secara reduksi cadmium. ICS 13.060.050.

Vesely, T., Tlustos, P., \& Szakova, J. (2011). The use of water lettuce (Pistia stratiotes L.) for rhizofiltration of a highly polluted solution by cadmium and lead. Inter. J. of Phytoremediation, 13(9), 859-872.

Wedemeyer, G. (1996). Physiology of fish in intensive culture systems. Springer Science $\&$ Business Media, $232 \mathrm{pp}$.

Zonneveld, N., Huisman, E.A., \& Boon, J.J. (1991). Prinsip-prinsip budidaya ikan. Jakarta: Gramedia Pustaka, 318 pp. 